\title{
Redescription and phylogenetic analyses of Durchoniella spp. (Ciliophora, Astomatida) associated with the polychaete Cirriformia tentaculata (Montagu, 1808)
}

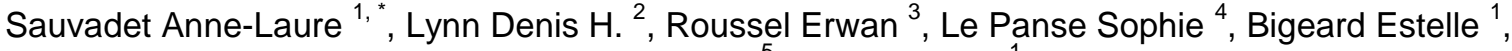 \\ Schrével Joseph ${ }^{5}$, Guillou Laure ${ }^{1}$
}

${ }^{1}$ Sorbonne Universités, Université Pierre et Marie Curie-Paris 6, CNRS, UMR 7144, Station

Biologique de Roscoff, Place Georges Teissier, CS90074, 29688 Roscoff cedex, France

${ }^{2}$ Department of Integrative Biology, University of Guelph, N1G 2W1 Guelph, ON Canada

${ }^{3}$ School of Earth and Ocean Sciences, Cardiff University, Main Building, Park Place, Cardiff, Wales, UK

${ }^{4}$ CNRS, FR 2424, Service Informatique et Génomique, Station Biologique de Roscoff, 29680 Roscoff,

France

${ }^{5}$ Muséum National d'Histoire Naturelle, Département RDDM, CNRS UMR 7245, CP 52, 61 Rue Buffon, 75231 Paris Cedex 05, France

*Corresponding author : Anne-Laure Sauvadet, email address : annelaure.sauvadet@gmail.com

\begin{abstract}
:
Microscopic and phylogenetic analyses were performed on endocommensal astome ciliates retrieved from the middle intestine of a marine cirratulid polychaete, Cirriformia tentaculata, collected in the bay of Roscoff (English Channel, Northwest French coast) and on the Southwest English coast. Three morphotypes of the astome genus Durchoniella were identified, two corresponding to described species (the type species Durchoniella brasili (Léger and Duboscq, 1904) de Puytorac, 1954 and Durchoniella legeriduboscqui de Puytorac, 1954) while a third morphotype remains undescribed. Their small subunit (SSU) rRNA gene sequences showed at least $97.2 \%$ identity and phylogenetic analyses grouped them at the base of the subclass Scuticociliatia (Oligohymenophorea), as a sister lineage to all astomes from terrestrial oligochaete annelids. Ultrastructural examination by transmission electron microscopy and fluorescence in situ hybridization analyses revealed the presence of endocytoplasmic cocci and rodshaped bacteria surrounded by a very thin membrane. These endocytoplasmic bacteria may play a role in the association between endocommensal astome ciliates and cirratulid polychaetes inhabiting in anoxic coastal sediments.
\end{abstract}

Keywords: Astomatida, Ciliophora, Cirratulidae, Endocytoplasmic bacteria, Microscopy, Molecular phylogeny 
Sauvadet, et al.

\section{Introduction}

Unicellular ciliates are genetically and morphologically diverse ( 8000 described species, Lynn 2008), mainly characterized by dimorphic nuclei and the presence of cilia at least once during their life cycle. Ciliates are typically active free-living grazers that generally have an oral cavity used during phagotrophy, although they can also perform pinocytosis and cell surface absorption (Corliss 1979; Lynn 2008). Most ciliates that live in association with metazoans are commensals, but parasitic interactions are also clearly established for some species (e.g. Ewing and Kocan 1992). Moreover, ciliates hosting prokaryotes are widespread (for review, Fokin 2004; Görtz 2001) and these associations seem to be frequent in distinct environments, including hydrothermal vents (Kouris et al. 2007) and anoxic habitats (e.g. Ott et al. 2005). Prokaryotic symbionts may play nutritive and defensive roles, or may also be used to modify surrounding and intrasecal environmental conditions (for review, Gast et al. 2009).

Astome ciliates were first observed in 1788 (Müller 1788). However, their anatomy and habitat were first described during the $20^{\text {th }}$ century (Cépède 1910; de Puytorac 1954). They are endocommensals living mainly in association with annelids, frogs, and toads (de Puytorac 1954). No free-living astome species have been described so far. Astomes are all mouthless, and they use a thigmotactic field, or specialized structures in the form of hooks, spines or suckers, to attach themselves to their host. As astomes do not seem to damage host tissues, it has been suggested that the intestine of their host could represent a stable ecological niche that concentrates specific nutrients (de Puytorac 1954). However, their ecology is still poorly understood. Based upon morphological criteria, astomes are commonly placed within the subclass Astomatia in the class Oligohymenophorea (de Puytorac 1994; 
Sauvadet, et al.

Jankowski 2007; Lynn 2008). Jankowski (2007) and de Puytorac (1994) further divide the subclass into three orders - Hoplitophryida, Anoplophryida, and Haptophryida while Lynn (2008) maintains a single order Astomatida with its included families. The analysis of a small subunit (SSU) rRNA gene sequence of Anoplophrya marylandensis Conklin, 1930, an astome retrieved from the intestine of a lumbricid annelid, confirmed their affiliation to the Oligohymenophorea (Affa'a et al. 2004). Nine other species of astomes from oligochaete hosts were sequenced subsequently confirming the monophyly of this subclass (Fokam et al. 2011).

The genus Durchoniella de Puytorac, 1954 includes four species (i.e. the type species $D$. brasili, $D$. legeriduboscqui, $D$. cirratuli and $D$. dodecaceriae), all retrieved from marine cirratulid polychaetes (Léger and Duboscq 1904; de Puytorac 1954; de Puytorac and Schrével 1965). The major criteria used for the identification of these species are the size and the general shape of cells, the number and arrangement of contractile vacuoles and the number of kineties. Durchoniella brasili (Léger and Duboscq, 1904) de Puytorac, 1954 and D. legeriduboscqui de Puytorac, 1954 are exclusively observed in the middle intestine of one host, Cirriformia tentaculata Montagu, 1808 (also commonly named Audouinia tentaculata), a widespread cirratulid polychaete along European coasts. This marine worm lives in sediments characterized by reduced and low-oxygen conditions (George 1964). Cirriformia tentaculata lives in the upper sediment layers and traps food particles falling onto the sediment surface with its tentacular filaments (Fauvel 1927). These filaments are also used to acquire oxygen. To avoid predation during low tide, worms bury themselves deeply into the sediment retracting their tentacles, encountering therefore chronic anoxic conditions (Bestwick et al. 1989). 
Sauvadet, et al.

The aim of the present study was to assess the phylogenetic position of Durchoniella species from the cirratulid polychaete $C$. tentaculata, morphologically identified based on the literature (Léger and Duboscq 1904; de Puytorac 1954; de Puytorac and Schrével 1965; Tchang 1931), and to re-investigate these species using light and transmission electron microscopy.

\section{Material and Methods}

\section{Site description and sampling}

Intestinal contents of Cirriformia tentaculata, collected between March 2009 and May 2010 from several different sites at Roscoff (Souris Island, SI; $03^{\circ} 59^{\prime} \mathrm{W}, 48^{\circ} 43^{\prime} \mathrm{N}$; France), Plymouth and Portsmouth $\left(04^{\circ} 9.80^{\prime} \mathrm{W}, \quad 50^{\circ} 21.87^{\prime} \mathrm{N}\right.$ and $01^{\circ} 1.90^{\prime} \mathrm{W}$, $50^{\circ} 47.80^{\prime} \mathrm{N}$; UK) were examined. Cirratulids were meticulously cleaned with $0.2 \mu \mathrm{m}$ filtered seawater by removing all grains of sand with forceps. Each worm was then placed individually in a 6-well plate filled with $10 \mathrm{~mL}$ filtered seawater and maintained up to eight weeks at room temperature with a daily seawater renewal without nutrient addition. Dissections were performed after worms were incubated for at least $30 \mathrm{~min}$ in $7 \%(\mathrm{w} / \mathrm{v}) \mathrm{MgCl}_{2}$ in filtered seawater, prepared at least $2 \mathrm{~h}$ in advance and stored at $4^{\circ} \mathrm{C}$.

\section{Light, epifluorescence and electron microscopy}

Living and fixed material extracted from worms were examined from freshly prepared slides and photographed with an Olympus BX51 epifluorescence microscope (Olympus Optical CO, Tokyo, Japan), coupled to a Spot RT-slider camera (Diagnostics Instruments, Sterling Heights, MI). From a $2 \mathrm{~g} / \mathrm{L}$ stock solution of Neutral Red, cells were incubated $15 \mathrm{~min}$ in a $50 \mathrm{mg} / \mathrm{L}$ solution at room temperature, and rinsed twice with filtered-sterilized-filtered $(F / S / F)$ seawater. DAPI colorations $(0.225$ 
Sauvadet, et al.

$\mu \mathrm{g} / \mathrm{mL}$ final concentration) were realized on glutaraldehyde $(0.25 \%(\mathrm{v} / \mathrm{v}))$ or paraformaldehyde $(4 \%(\mathrm{w} / \mathrm{v}))$ fixed cells in AF1 solution (Glycerol + PBS, CytiFluor, London, UK). For silver impregnation, cells were fixed in Champy's and then Da Fano's fluids (or glutaraldehyde for some cells) before staining as described elsewhere (Lynn et al. 1981). For scanning electron microscopy (SEM), cells were fixed for $4 \mathrm{~h}$ at room temperature in a fixative containing $4 \%(\mathrm{v} / \mathrm{v})$ glutaraldehyde, $0.25 \mathrm{M}$ sucrose, and $0.1 \mathrm{M}$ sodium cacodylate $\mathrm{pH}$ 7.4. Samples were then rinsed in a series of buffer solutions containing graded concentrations of sucrose and post-fixed for $1 \mathrm{~h}$ at $4^{\circ} \mathrm{C}$ in $1.5 \%(\mathrm{w} / \mathrm{v}) \mathrm{OsO}_{4}$ in $0.2 \mathrm{M}$ cacodylate $\mathrm{pH} 7.4$ and $0.33 \mathrm{M} \mathrm{NaCl}$. Dehydration was carried out in graded alcohol series and finally dried using a critical point dryer (CPD 030 Bal-Tec, Balzers, Lichtenstein). The dried cells were coated with gold in a sputter coater before observation with a JSM 5200 SEM (JEOL Ltd., Tokyo, Japan). The fixation process for transmission electron microscopy (TEM) was as described for SEM above. After dehydration, samples were then embedded in Epon $^{\mathrm{TM}}$. Sections were made using a diamond knife on a Leica Ultracut UCT ultramicrotome (Leica Mikrosysteme $\mathrm{GmbH}$, Wetzlar, Germany), stained with uranyl acetate and lead citrate, and observed with a JEM 1400 transmission electron microscope (JEOL Ltd., Tokyo, Japan) or a Quanta 200 environmental SEM (FEl, Hillsboro, Oregon, USA).

\section{Bacterial FISH}

General probe Eub338 (Amann et al. 1990) was used to observe bacteria by in situ hybridization in both Durchoniella species. Non-sense probes (EUBN) were also used as negative controls and no signal was detected. All probes were synthesized with Cyanine-3 at the 5'-end (Thermo Fisher Scientific GmbH, Ulm, Germany). The probes, received in a lyophilized form, were dissolved in sterile deionised water 
Sauvadet, et al.

purified with the MilliQ system from Millipore (resistivity $18 \mathrm{M} \Omega$ ) to a final concentration of $50 \mathrm{ng} / \mu \mathrm{L}$ and aliquots stored in the dark at $-80^{\circ} \mathrm{C}$.

Cells were individually collected with drawn glass pipette and placed on coated slides (Polysine ${ }^{\circledR}$ slides, Menzel $\mathrm{GmbH}$, Brainschweig, Germany). Cells were fixed for 10 $\min$ in $4 \%(w / v)$ paraformaldehyde solution and dehydrated with $80 \%$ ethanol for 10 min. Cells were then incubated with proteinase $\mathrm{K}(5 \mu \mathrm{g} / \mathrm{mL}$ final concentration) and lysozyme $\left(2 \mathrm{mg} / \mathrm{mL}\right.$ final concentration) at $37^{\circ} \mathrm{C}$ for $1 \mathrm{~h}$. Rinsing and pre-hybridization were performed for $10 \mathrm{~min}$ at $46^{\circ} \mathrm{C}$ in hybridization buffer $(40 \%(\mathrm{v} / \mathrm{v})$ formamide in $5 \mathrm{X}$ SSC, where $5 \mathrm{X}$ SSC $=83 \mathrm{mM} \mathrm{NaCl}, 83 \mathrm{mM}$ sodium citrate, $\mathrm{pH} 7.0$ ). Hybridizations with each fluorescent probe were performed on slides in a hybridization chamber (Evergreen Scientific, Los Angeles, USA) at $46^{\circ} \mathrm{C}$ for $10 \mathrm{~min}$ in $300 \mu \mathrm{L}$ of hybridization buffer containing the probes at a final concentration of $5 \mathrm{ng} / \mu \mathrm{L}$. After hybridization, cells were washed twice in a bath of $5 \mathrm{XSC}$ at $48^{\circ} \mathrm{C}$ for $10 \mathrm{~min}$. Slides were mounted in anti-fading reagent $\mathrm{AF} 1$ and stored at $4^{\circ} \mathrm{C}$ in the dark until they were observed.

\section{DNA extraction}

Before DNA extraction, worms were rinsed three times, all equipment (dissection tools, dissection boxes and jar) was incubated in DNA AWAY ${ }^{\circledR}$ (Molecular BioProducts $\left.{ }^{\mathrm{TM}}\right)$, ethanol, and sterilized for $30 \mathrm{~min}$ at $121^{\circ} \mathrm{C}$. Single-cells of Durchoniella sp. were then isolated with sterilized drawn glass pipettes and rinsed individually three times in filtered/sterilized/filtered seawater. DNA of single-cells was extracted by a modified Guanidinium Isothiocyanate (GITC) protocol (Chomczynski and Sacchi 1987, 2006). Each fresh single-cell was ground in $50 \mu \mathrm{L}$ of the GITC extraction buffer, and crushed with a tube-adapted piston pellet (Kimble Chase ${ }^{\circledR}$ ) for at least one minute. Tubes were incubated for $20 \mathrm{~min}$ at $72^{\circ} \mathrm{C}$, and quickly 
Sauvadet, et al.

centrifuged. One volume of cold isopropanol was added at $-20^{\circ} \mathrm{C}$ overnight. After centrifugation for $15 \mathrm{~min}$ at $14,000 \mathrm{~g}$ at $4^{\circ} \mathrm{C}$ and one washing with $70 \%(\mathrm{v} / \mathrm{v})$ ethanol, the DNA pellet was hydrated in sterile distilled water and stored at $4^{\circ} \mathrm{C}$. The extraction product was used to amplify SSUrRNA genes.

\section{PCR and sequencing}

All PCR mixtures (30 $\mu \mathrm{L}$ final volume) contained $1 \mathrm{X}$ Taq DNA Polymerase buffer, 1 $\mu \mathrm{L}$ of dNTPs (20 mM each), $3 \mu \mathrm{L}$ of $\mathrm{MgCl}_{2}(25 \mathrm{mM}), 0.1 \mu \mathrm{L}$ of each primer $(100 \mu \mathrm{M})$ and $0.25 \mu \mathrm{L}$ of Taq DNA Polymerase (5 unit/ $\mu \mathrm{L}$, Promega ${ }^{\circledR}$, Madison, Wisconsin). All amplifications were performed using a "GeneAmp PCR system" 9700® (Applied Biosystems $^{\mathrm{TM}}$ ) or "MJ Mini Cycler" (Biorad $\left.{ }^{\mathrm{TM}}\right)$. Negative controls were also carried out with DNA extractions performed with no sample, with and without piston pellet. For all negative controls, no PCR products were detected.

Eukaryotic SSUrRNA genes were amplified with primers EukMK_63F/EukMK_1818R (5'-ACG CTT GTC TCA AAG ATT A-3'; 5'-ACG GAA ACC TTG TTA CGA-3'; M. Kawachi, unpublished) with the following conditions: one cycle of 5 min at $95^{\circ} \mathrm{C}, 30$ cycles of $1 \mathrm{~min}$ at $95^{\circ} \mathrm{C}, 1.5 \mathrm{~min}$ at $57^{\circ} \mathrm{C}$ and $1.5 \mathrm{~min}$ at $72^{\circ} \mathrm{C}$ and one cycle of $10 \mathrm{~min}$ at $72^{\circ} \mathrm{C}$. PCR cycles were as follows: one cycle of $5 \mathrm{~min}$ at $94^{\circ} \mathrm{C}, 30$ cycles of $1 \mathrm{~min}$ at $94^{\circ} \mathrm{C}, 1.5 \mathrm{~min}$ at $49^{\circ} \mathrm{C}$ and $2 \mathrm{~min}$ at $72^{\circ} \mathrm{C}$ and one cycle of $6 \mathrm{~min}$ at $72^{\circ} \mathrm{C}$. Three independent PCR products were pooled and purified (QIAquick PCR purification Kit; Qiagen $^{\mathrm{TM}}$ ) and cloned into Escherichia coli (One Shot F10', Promega ${ }^{\mathrm{TM}}$ ) using the pCR2.1-TOPO TA vector system $\left(\right.$ Invitrogen $^{\circledR}$ ) following the manufacturer's instructions. Positive transformants were screened by PCR amplification of the insert using the vector-specific M13 primers. Positive PCR products were purified (ExoSAP$\mathrm{IT}^{\circledR}$ For PCR Product Clean-Up, USB ${ }^{\mathrm{TM}}$ ) and sequenced in both directions with 
Sauvadet, et al.

specific primers using the Big Dye Terminator Cycle Sequencing Kit 3.0 (PE Biosystems $^{\mathrm{TM}}$ ) and an ABI PRISM model 377 (version 3.3) automated sequencer.

\section{Phylogenetic analyses}

Sequences were edited in the BioEdit 7.0.5.3 program and aligned using CLUSTALW2 version 2.0.10 (Hall 1999; Larkin et al. 2007). To determine the first phylogenetic affiliation, each sequence was compared with sequences available in the NCBI database (National Center for Biotechnology Information) using BLAST (Altschul et al. 1990). For the Oligohymenophorea tree (Fig. 5), a general timereversible $(G T R+\mid+G)$ model with gamma distributed rates and a proportion of invariable sites was selected by hierarchical Likelihood Ratio Tests (hLRT), via jModeltest 0.1 .1 (Posada 2008) and used as a model of nucleotide substitution for the phylogenetic inference of each sequence by Maximum Likelihood (ML) and Bayesian inference (BI) (Posada and Crandall 1998). ML was conducted using PhyML 3.0 (Guindon et al. 2005) and the robustness of the inferred topology was tested by bootstrap resampling (100). BI was conducted using MrBayes 3.1.2 (Huelsenbeck and Ronquist 2001) and started with a random tree, run for 356000 generations in four chains (Standard deviation $=0.009$ ) and a burn-in of 890 generations in order to ensure the use of only stable chains. Neighbour Joining (NJ) and Maximum of Parsimony (MP) trees were inferred using PAUP $4.0 \mathrm{~b} 10$ via PaupUp graphical interface (Swofford 2000; Calendini and Martin 2005). The robustness of the inferred topologies was supported by bootstrap resampling (1000) with NJ and MP; values over $50 \%$ are shown on the tree. The ML trees gave the same topologies as the BI trees. Trees were visualised and labelled with TreeDyn (Chevenet et al. 2006). 
Sauvadet, et al.

\section{Voucher slides}

Three Chatton-Lwoff silver-stained cell slides are deposited in the protist collection of the National Museum of Natural History, Paris, France. The reference numbers are: ZS123 for Durchoniella legeriduboscqui genotype Dld1-G12 (isolate 1, Glutharaldehyde tube 12); ZS124 for Durchoniella legeriduboscqui genotype Dld2G13-1 (isolate 2, Glutharaldehyde tube 13-1); and ZS125 for Durchoniella brasili 5.

\section{Nucleotide sequence accession numbers}

The SSU rRNA gene sequences are available from the GenBank database under the following accession numbers: FN998987 to FN999022.

\section{Results}

\section{Identification of Durchoniella species retrieved from Cirriformia tentaculata}

Cirriformia tentaculata specimens were retrieved from anoxic sediments (Fig. 1A), between 3 to $15 \mathrm{~cm}$ depth, from the bay of Roscoff, France (English Channel) or from the English coast near Plymouth and Portsmouth. The sediments were characterized by a black colour (Fig. 1B) and sometimes a strong hydrogen sulphide odour. Six 20g samples from the sediments and the interstitial water surrounding the worms were analysed by light microscopy. Amoebae, copepods, eggs similar to those retrieved from Cirriformia, as well as unicellular cells were observed in the interstitial waters and in the sediment matrix. However, no free Durchoniella-like cells were identified.

Durchoniella-like cells from the host intestine fell into two morphotypes/genotypes that we were able to assign to previously described species, and a third morphotype/genotype for which we have been unable to obtain sufficient cells for morphometric analysis. Cells were observed in the middle intestine of C. tentaculata, not fixed to the epithelial tissue of the host and were always located around the 
Sauvadet, et al.

alimentary bolus (Fig. 1C, D). After dissection, a large number of vigorously swimming ciliated cells of distinct sizes was usually observed. Swimming behaviour of these ciliates was clearly different, the largest cells swimming faster than the smallest ones. However, some cells remained stuck in a viscous gel-like liquid.

Durchoniella brasili (Léger and Duboscq, 1904) de Puytorac, 1954 (Figs. 2A-G, 3A-J, 4D-E; Table 1). It was the smallest species described so far and was often truncated or rounded at the posterior end (Fig. 2A, B, E; Fig. 4D). Based on 34 living cells, the somatic length ranged in vivo between $75-170 \mu \mathrm{m}$, the somatic width between 29-103 $\mu \mathrm{m}$. The number of contractile vacuoles on 20 cells ranged between 2-6 (Table 1).

The elongated uneven macronucleus has extensions in glutaraldehyde-fixed material that appeared to be part of an external layer that surrounds an elongate and smooth inner region (Figs. 2A, 3A). The macronucleus was between 65-144 $\mu \mathrm{m}$ in length and 10-33 $\mu \mathrm{m}$ in width on 12 living cells (Table 1).

The total number of somatic kineties on fixed cells ranged between $65-81$ and $61-78$ respectively on glutaraldehyde $(n=12)$ and Champy's-DaFano's $(n=16)$ fixed material (Table 1). It was however difficult to accurately count the number of lateral kineties on silver-stained cells.

In the few cells where the anterior suture region was visible, it had a pattern of four points with the right ventrolateral one being the most prominent (Figs. 2B, 4D-E). The anterior skeletal structure was a large pyramid-shaped structure with four basal extensions and a non-chitinous papilla at the anterior end of the cell (Fig. 2B, F; Fig. 4D-E).

Durchoniella legeriduboscqui de Puytorac, 1954 (Figs. 2A-G, 3A-J, 4A-C; Table 1). Based on 21 living cells, the somatic length ranged in vivo between 180-350 $\mu \mathrm{m}$, 
Sauvadet, et al.

the somatic width between $75-90 \mu \mathrm{m}$. The number of contractile vacuoles on 15 cells ranged between 6-15 (Table 1).

The elongated uneven macronucleus has extensions in glutaraldehyde-fixed material that appeared to be part of an external layer that surrounds an elongate and smooth inner region (Figs. 2C, 3B). The macronucleus was between $277-340 \mu \mathrm{m}$ in length and 49-97 $\mu \mathrm{m}$ in width on 6 living cells (Table 1).

The total number of somatic kineties on fixed cells ranged between 97-121 and 103128 respectively on glutaraldehyde $(n=46)$ and Champy's-DaFano's $(n=8)$ fixed material (Table 1). As noted above, we cannot assume that our estimates are accurate as there is some uncertainty in counting the numbers of "lateral" kineties. We report a minimal number of somatic kineties as 97-128 when we could count those on the entire cell; if we double the number of inferior kineties, which is roughly the relation between inferior or ventral and superior or dorsal kinety numbers, our range is $96-134$ (Table 1 ).

In cells where the anterior suture region was visible, it had a pattern of three points with the right ventrolateral one being the most prominent (Fig. 2D, 4A-C). The anterior skeletal structure was a large tripod-shaped structure with three basal extensions and a non-chitinous papilla at the anterior end of the cell (Fig. 2D, G; Fig. 4B).

In both species, vegetative divisions took place by binary fission (D. brasili, Fig. 3C, D; D. legeriduboscqui, Fig. 3E, F). However, only micronuclei already divided and macronuclei under elongation were observed (Fig. 3D, F). Conjugation was only rarely observed in $D$. brasili, once in more than 20,000 Durchoniella cells analysed over more than a year (Fig. 3G-J). Two pairing cells were observed, still motile, of equal size and attached at the same level by their apical extremities, forming an 
Sauvadet, et al.

acute angle (Fig. 3G-I). At this stage, four micronuclei per cell were identified by DAPI staining (Fig. 3J).

\section{Phylogenetic analyses of Durchoniella species based on Small Subunit (SSU) rRNA gene sequences}

From 60 C. tentaculata worms dissected, the total DNA was extracted from 115 ciliate individuals and the SSURRNA gene was directly sequenced after PCR amplification. We assigned 74 of them to the morphotype corresponding to the smallest Durchoniella morphotype. This was supported by SSUrRNA sequences that differed by less than $0.4 \%$ (based on $1626 \mathrm{bp}$ ) among the most divergent isolates (representative sequence FN998990, Fig. 5). The remaining 41 cells, assigned to $D$. legeriduboscqui based on somatic length and shape, were collected from Plymouth, Portsmouth, and Roscoff (Table 1). The SSUrRNA sequences of six isolates morphometrically characterized from these localities were identical to the SSUrRNA sequences of 27 other cells (based on $1626 \mathrm{bp}$ and represented by sequence FN998995, Fig. 5). Since it was the most common morphotype and genotype of the larger Durchoniella-like cells, we assigned these 33 cells to D. legeriduboscqui, the only other large Durchoniella species from C. tentaculata previously described to have one row of contractile vacuoles. The remaining eight cells were assigned to Durchoniella sp. The SSUrRNA sequences of these cells (represented by sequence FN998993, Fig. 5) differed by $2.8 \%$ from sequences of $D$. legeriduboscqui (represented by sequence FN998995, Fig. 5). They morphologically resembled $D$. legeriduboscqui based on cell size, cell shape, and numbers of contractile vacuoles, which were also distributed in a single row.

Using ML and $\mathrm{BI}$ methods, D. brasili, D. legeriduboscqui, and Durchoniella sp. were shown to form a monophyletic clade in the subclass Astomatia, and this clade is 
Sauvadet, et al.

sister to the clade formed by the ten other astome sequences retrieved from the intestinal contents of oligochaete annelids (Fokam et al. 2011) (Fig. 5). The relationship between all of these astome species was supported by a posterior probability of $1.0, \mathrm{ML}$ bootstrap of $94 \%$, NJ bootstrap of $100 \%$, and MP bootstrap of $93 \%$. They formed a cluster associated with the subclass Scuticociliatia within the class Oligohymenophorea, a position supported by a posterior probability of $0.98, \mathrm{ML}$ bootstrap of $92 \%$, NJ bootstrap of $93 \%$, and MP bootstrap of $65 \%$ (Fig. 5).

\section{Microscopic evidence of endocytoplasmic bacteria}

Transmission electron microscopy (TEM) revealed numerous prokaryotic-like bodies that were not observed using scanning electron microscopy (SEM), light microscopy or differential interference contrast (DIC) microscopy. Fluorescence in situ hybridization (FISH) analysis using a general bacterial probe (EUB338) confirmed the presence of these bacteria in the cytoplasm of all $D$. brasili and $D$. legeriduboscqui (Fig 6A, B). No positive signal was observed using the general archaeal probe ARCH915. These numerous endocytoplasmic bacteria were freely distributed throughout the cytoplasm of the Durchoniella cells (Fig. 6C). Although bacteria were not incorporated in food vacuoles or in association with nuclei or other eukaryote organelles, all the bacteria observed by TEM were surrounded by an electrontranslucent halo delimited by a very thin membrane (Fig. 6D, white and black arrow; Fig. 6E, black arrowheads). All bacteria observed had two membranes (Fig. 6D, black arrows), contained granular cytoplasm and nucleoid-like structures (Fig. 6D-G). Rod-shaped and coccoid bacteria, 2-3 $\mu \mathrm{m}$ long and 0.5-0.8 $\mu \mathrm{m}$ of diameter, were observed by TEM (Fig. 6D-G) and by FISH (Fig 6A, B). Division of these endocytoplasmic bacteria was suggested by TEM observations (Fig. 6G). Bacteria were not motile inside Durchoniella cells and no flagellum was observed. 
Sauvadet, et al.

\section{Discussion}

\section{Durchoniella species}

The somatic length, somatic width, and the number of contractile vacuoles of our isolates identified as $D$. brasili and $D$. legeriduboscqui fell within or overlapped the ranges provided by de Puytorac (1954) but never reached the maximum length observed by Léger and Duboscq (1904) for $D$. brasili (Table 1). The macronucleus width again overlapped the range provided by de Puytorac (1954). Our observations on the anterior skeletal structures on both species were consistent with the description of this author.

In the case of $D$. brasili, the number of somatic kineties was also similar to that provided by de Puytorac (1954), but corresponded to half the number reported by Léger and Duboscq (1904) or Tchang (1931) (Table 1). Like A. brasili, which was named after colleague L. Brasil, D. legeriduboscqui de Puytorac, 1954 was initially assigned to the genus Anoplophrya by Léger and Duboscq (1904). Tchang (1931) recollected what he called $A$. brasili in France, in the same region as in 1904, and, using Chatton-Lwoff silver impregnation, redescribed it with the same genus assignment as Léger and Duboscq (1904). De Puytorac (1954) based his analysis of $D$. legeriduboscqui on this latter redescription along with his own observations. In our case, the number of somatic kineties never reached the number of 138-140 provided by de Puytorac (1954), Léger and Duboscq (1904), and Tchang (1931) (Table 1). However, these authors provided no evidence of variability in this feature nor reported how many cells were measured.

\section{Systematic position of astomes}

Durchoniella brasili and D. legeriduboscqui were placed by de Puytorac (1994) within the class Oligohymenophorea, subclass Astomatia, order Hoplitophryida, family 
Sauvadet, et al.

Radiophryidae, and subfamily Durchoniellinae de Puytorac, 1972, a classification supported by Jankowski (2007) down to the family level. This systematic position of astomes is still controversial, as de Puytorac considered the group polyphyletic (de Puytorac 1954, 1994; de Puytorac et al. 1979), whereas Lynn (2008) classified all astomes within the order Astomatida. The common presence of a thigmotactic field and an apical structure in astomes suggests a common ancestry with the Hysterocinetidae (de Puytorac 1994; Lynn 2008; Ngassam et al. 1994). However, our phylogenetic analyses with two thigmotrich sequences (i.e. Hemispeiridae and Ancistridae; Gao et al. 2010, 2012; Fig. 5) demonstrated that thigmotrichs and astomes are not sister taxa as both thigmotrich sequences clustered robustly within the Scuticociliatia.

The first phylogenetic study of a SSUrRNA gene sequence retrieved from an astome suggested that this group belonged to the class Oligohymenophorea, and placed astomes sister to the Scuticociliatia (Affa'a et al. 2004). The analysis of nine other SSUrRNA gene sequences from astomes associated with terrestrial oligochaetes confirmed this placement and additionally suggested the monophyly of the subclass Astomatia. The tree topology in the present analysis supported, with high statistical confidence levels, the monophyly of $D$. brasili, $D$. legeriduboscqui, and Durchoniella sp. with all other members of Astomatia within the class Oligohymenophorea. Durchoniella SSUrRNA gene sequences grouped, however, in a monophyletic clade with robust statistical support from the other available sequences of astomes that are assigned to the families Radiophryidae (Eudrilophrya, Metarocoelophrya, Metaradiophrya), Anoplophryidae (Almophrya, Anoplophrya, Njinella) and Clausilocolidae (Paraclausilocola). This result suggests that Durchoniellinae is not a subfamily of the Radiophryidae, but could represent a novel order within de 
Sauvadet, et al.

Puytorac's classification, or a family within Lynn's classification. As SSUrRNA gene sequences of hysterocinetid ciliates are not available, it is still not possible to decide conclusively on the phylogenetic origin of astomes. Presuming astome genera and species have been identified correctly, the SSUrRNA gene sequences from $D$. brasili and $D$. legeriduboscqui grouped into distinct clusters (data not shown), confirming the initial morphological diagnosis of two distinct species. Given the genetic similarity of these two Durchoniella morphospecies, we believe the eight diverging sequences belong to the genus Durchoniella probably as a new species, but more evidence should be provided for its characterization.

\section{A third "Russian nesting doll": the bacteria}

Endosymbiotic bacteria in astomes was first reported in specimens retrieved from the oligochaete Lumbriculus variegatus (Hovasse 1945), and subsequent research showed that several astomes also harbour bacteria (Hovasse 1946). This endosymbiotic association does not seem to be required for all astomes as several species are free from bacteria, such as Spirobuetschiella chattoni and Cepedella hepatica (Hovasse 1946). Bacteria were not previously observed in Durchoniella from C. tentaculata sampled at Roscoff using an acid fuchsin-azure II stain (Hovasse 1946), whereas we observed endocytoplasmic bacteria in $D$. brasili and also in $D$. legeriduboscqui by combining FISH staining and transmission electron microscopy. Microscopic observation using DAPI showed that the endocytoplasmic bacteria were equally distributed in the Durchoniella cells during conjugation (data not shown). The

same observation was also made during binary fission using SYBR green staining and FISH analysis (data not shown), suggesting that bacterial symbionts are acquired by vertical transmission. However, further molecular genetic analyses of the biogeographic distribution would be required to verify this particular point. While the 
Sauvadet, et al.

ecology of this association remains to be explored, these endocytoplasmic bacteria may play a role in the association between endocommensal astome ciliates and cirratulid polychaetes inhabiting in anoxic coastal sediments.

\section{Acknowledgements}

The authors are deeply indebted to Professor Pierre de Puytorac for his pioneering works on these astome species and his fruitful comments. We thank Morgan Perennou and Gwenn Tanguy (Ouest-Genopole platform®) for sequencing operations. This work was supported by the ANR HAPAR awarded to L.G. and by a Natural Sciences and Engineering Research Council of Canada Discovery Grant (NF12-04977) awarded to D.H.L. A.L. Sauvadet was supported by a grant from the Ministère de la Recherche. 


\section{References}

Affa'a, F.M., Hickey, D.A., Struder-Kypke, M., Lynn, D.H. 2004. Phylogenetic position of species in the genera Anoplophrya, Plagiotoma, and Nyctheroides (phylum ciliophora), endosymbiotic ciliates of annelids and anurans. J. Euk. Microbiol. 51, 301-306.

Altschul, S.F., Gish, W., Miller, W., Myers, E.W., Lipman, D.J., 1990. Basic local alignment search tool. J. Mol. Biol. 215, 403-410.

Amann, R.I., Binder, B.J., Olson, R.J., Chisholm, S.W., Devereux, R., Stahl, D.A., 1990. Combination of 16S Ribosomal-RNA-Targeted oligonucleotide probes with flow-cytometry for analyzing mixed microbial-populations. Appl. Environ. Microbiol. 56, 1919-1925.

Bestwick, B.W., Robbins, I.J., Warren, L.M., 1989. Metabolic adaptations of the intertidal polychaete Cirriformia tentaculata to life in an oxygen-sink environment. J. Exp. Mar. Biol. Ecol. 125, 193-202.

Calendini, F., Martin, J.-F., 2005. PaupUP v1.0.3.1 A free graphical frontend for $\begin{array}{llll}\text { Paup* Dos } & \text { software. } & \text { URL: } & \text { http://www.agro- }\end{array}$ montpellier.fr/sppe/Recherche/JFM/PaupUp/

Cépède, C., 1910. Recherches sur les Infusoires astomes. Arch. Zool. Exp. et Gén. 3, 341-609.

Chevenet, F., Brun, C., Banuls, A.L., Jacq, B., Christen, R., 2006. TreeDyn: towards dynamic graphics and annotations for analyses of trees. BMC Bioinformatics 7, 439.

Chomczynski, P., Sacchi, N., 1987. Single-step method of RNA isolation by acid guanidinium thiocyanate phenol chloroform extraction. Anal. Biochem. 162, 156159. 
Sauvadet, et al.

Chomczynski, P., Sacchi, N., 2006. The single-step method of RNA isolation by acid guanidinium thiocyanate-phenol-chloroform extraction: twenty-something years on. Nat. Protoc. 1, 581-585.

Corliss, J.O., 1979. The Ciliated Protozoa: Characterization, classification, and guide to the Literature, 2nd edition. Pergamon Press, London \& New-York. pp. 455.

De Puytorac, P., 1954. Contribution à l'étude cytologique et taxonomique des infusoires astomes. Ann. Sci. Nat. Zool. 11e série, 85-270

De Puytorac, P., 1994. Traité de zoologie. Anatomie, systématique et biologie. Infusoires ciliés : systématique. Tome 2 Fasc. 2. Masson, Paris. pp. 880.

De Puytorac, P., Schrével, J., 1965. Nouvelles espèces de ciliés astomes endoparasites d'annélides polychètes. Annales de la faculté des sciences de Clermont-Ferrand 26, 85-99.

De Puytorac, P., Grolière, C.A., Grain, J., 1979. Nouveaux arguments (Hysterophrya gen. nov., Raabellocineta gen. nov.) en faveur de liaisons phylétiques possibles entre ciliés Astomotida et Scuticociliatida. C. R. Acad. Sci. Paris. 289, 857-859.

Ewing, M.S., Kocan, K.M., 1992. Invasion and development strategies of Ichthyophthirius multifiliis, a parasitic ciliate of fish. Parasitol. Today 8, 204-208. Fauvel, P., 1927. Polychètes sédentaires. In: Fédération française des sociétés de sciences naturelles (ed) Faune de France. Paris, pp. 494.

Fokam, Z., Ngassam, P., Struder-Kypke, M.C., Lynn, D.H., 2011. Genetic diversity and phylogenetic position of the subclass Astomatia (Ciliophora) based on a sampling of six genera from West African oligochaetes (Glossoscolecidae, 
Megascolecidae), including description of the new genus Paraclausilocola n. gen. Eur. J. Protistol. 47, 161-171.

Fokin, S.I., 2004. Bacterial endocytobionts of Ciliophora and their interactions with the host cell. Int. Rev. Cytol. 236, 181-249.

Gao, F., Fan, X.P., Yi, Z.Z., Struder-Kypke, M., Song, W.B., 2010. Phylogenetic consideration of two scuticociliate genera, Philasterides and Boveria (Protozoa, Ciliophora) based on 18S rRNA gene sequences. Parasitol. Int. 59: 549-555.

Gao, F., Struder-Kypke, M., Yi, Z.Z., Miao, M., Al-Farraj, S.A., Song, W.B., 2012. Phylogenetic analysis and taxonomic distinction of six genera of pathogenic scuticociliates (Protozoa, Ciliophora) inferred from small-subunit rRNA gene sequences. Int. J. Syst. Evol. Micr. 62: 246-256.

Gast, R.J., Sanders, R.W., Caron, D.A., 2009. Ecological strategies of protists and their symbiotic relationships with prokaryotic microbes. Trends Microbiol. 17: 563-569.

George, J.D., 1964. The life history of the cirratulid worm, Cirriformia tentaculata, on an intertidal mudflat. J. Mar. Biol. Assoc. U.K. 44, 47-65.

Görtz, H.-D., 2001. Intracellular bacteria in ciliates. Int. Microbiol. 4, 143-150.

Guindon, S., Lethiec, F., Duroux, P., Gascuel, O., 2005. PHYML Online - a web server for fast maximum likelihood-based phylogenetic inference. Nucleic Acids Res. 33, W557-W559.

Hall, T.A., 1999. BioEdit: a user-friendly biological sequence alignment editor and analysis program for Windows 95/98/NT. Nucl. Acid. S. 41, 95-98.

Hovasse, R., 1945. Endosymbiose bactérienne et astomie chez les ciliés. C. R. Acad. Sci. 221, 125-127. 
Sauvadet, et al.

Hovasse, R., 1946. Endosymbiose bactérienne chez divers ciliés parasites intestinaux. C. R. Acad. Sci. 223, 560-562.

Huelsenbeck, J.P., Ronquist, F., 2001. MRBAYES: Bayesian inference of phylogenetic trees. Bioinformatics 17, 754-755.

Jankowski, A. W. 2007. [Phylum Ciliophora Doflein, 1901]. In: Alimov, A. F. (Ed.), Protista. Part 2, Handbook on Zoology (pp. 415-993). St. Petersburg: Russian Academy of Sciences, Zoological Institute. (in Russian with English Summary).

Kouris, A., Juniper, S.K., Frebourg, G., Gaill, F., 2007. Protozoan-bacterial symbiosis in a deep-sea hydrothermal vent folliculinid ciliate (Folliculinopsis sp.) from the Juan de Fuca Ridge. Mar. Ecol. 28, 63-71.

Larkin, M.A., Blackshields, G., Brown, N.P., Chenna, R., McGettigan, P.A., McWilliam, H., Valentin, F., Wallace, I.M., Wilm, A., Lopez, R., Thompson, J.D., Gibson, T.J., Higgins, D.G., 2007. Clustal $W$ and clustal $X$ version 2.0. Bioinformatics 23, 2947-2948.

Léger, L., Duboscq, O., 1904. Notes sur les infusoires endoparasites. Arch. Zool. Exp. Gen. 2, 4e série , 337-356.

Lynn, D.H., 2008. The Ciliated Protozoa: characterization, classification, and guide to the literature. 3rd edition. Springer, Dordrecht. pp. 605.

Lynn, D.H., Suriano, D.M., Beverleyburton, M., 1981. Chatton-Lwoff silver impregnation - an improved technique for the study of Oncomiracidia (Platyhelminthes, Monogenea) Chaetotaxy. Syst. Parasitol. 3, 21-23.

Müller, O.F., 1788. Zoologia Danica, sen Animalium Daniae et Norvegiae rarium ac minus notorum. Descriptiones et Historia, Havniae.

Ngassam, P., De Puytorac, P., Grain, J., 1994. On Paraptychostomum almae nG, n-Sp, a commensal ciliate from the digestive-tract of oligochaetes of the 
Sauvadet, et al.

Cameroons, in a new subclass Hysterocinetia. J. Eukaryot. Microbiol. 41, 155162.

Ott, J., Bright, M., Bulgheresi, S., 2005. Marine microbial thiotrophic ectosymbioses. Oceanogr. Mar. Biol. 42, 95-118.

Posada, D., 2008. jModelTest: Phylogenetic model averaging. Mol. Biol. Evol. 25, 1253-1256.

Posada, D., Crandall, K.A., 1998. MODELTEST: testing the model of DNA substitution. Bioinformatics 14, 817-818.

Schloss, P.D., Handelsman, J., 2004. Status of the microbial census. Microbiol. Mol. Biol. Rev. 68, 686-691.

Swofford, D.L., 2000. PAUP*. Phylogenetic analysis using parsimony ("and other methods). Version 4. Sinauer Associates, Sunderland, Massachusetts Tchang, T.R., 1931. L'infraciliature et l'enkystement de l'Anoplophrya brasili, Léger et Duboscq. Bull. Soc. Zool. 56, 547-554. 
Sauvadet, et al.

\section{Captions}

Fig. 1A-D. Localisation of species of the astome ciliate Durchoniella from the cirratulid polychaete Cirriformia tentaculata. (A) Cirriformia tentaculata, with "a", the anterior part and "p", the posterior part. Scale bar $=1 \mathrm{~cm}$. (B) Example of a sampling site at Roscoff. Scale bar $=25 \mathrm{~cm}$. (C, D) Semi-thin transverse sections of $C$. tentaculata with dorsal (d) and ventral (v) sides indicated. The wall of the digestive tract is represented by the black arrows; the gut of the worm in $C$ is empty (white arrow). Scale bars $=100 \mu \mathrm{m}$. Longitudinal section of a specimen of Durchoniella brasili (top) and $D$. legeriduboscqui (bottom) were enlarged in parts of semi-thin sections. Scale bars $=20 \mu \mathrm{m}$.

Fig. 2A-G. Durchoniella brasili (A, B, E, F) and Durchoniella legeriduboscqui (C, D, E, G). DIC of living specimens (A, C), after Chatton-Lwoff silver preparation (B, D), and in SEM (E-G) with a zoom on fixative apparatus of the anterior end (F-G). Mi: Micronucleus; Ma: macronucleus; CV: Contractile vacuoles, revealed with neutral red staining in A. Bars: $20 \mu \mathrm{m}(\mathrm{A}), 70 \mu \mathrm{m}(\mathrm{B}), 50 \mu \mathrm{m}(\mathrm{C}-\mathrm{E}), 10 \mu \mathrm{m}(\mathrm{F}), 5 \mu \mathrm{m}(\mathrm{G})$.

Fig. 3A-J. Durchoniella brasili (A, C, D, G, H, I, J) , and Durchoniella legeriduboscqui (B, E, F). Drawings of macronuclei based on silver impregnation (A, B). DIC Nomarski observation (with DAPI coloration) during binary fission, arrows indicate fission furrow (C-F). Conjugation process, with zoom on conjugation junction and nuclear content of the two conjugants (G-J). Bars: $30 \mu \mathrm{m}(\mathrm{A}), 50 \mu \mathrm{m}(\mathrm{B}), 20 \mu \mathrm{m}(\mathrm{C}-\mathrm{G}$, J), $10 \mu \mathrm{m}(\mathrm{H}-\mathrm{I})$.

Fig. 4A-E. Micrographs of Chatton-Lwoff silver-stained Durchoniella legeriduboscqui (A-C) and Durchoniella brasili (D-E) isolated from the intestine of the cirratulid polychaete Cirriformia tentaculata at Roscoff (France). Ventral views (A, D). Anterior 
Sauvadet, et al.

secant systems (B, E). Posterior secant system (C). Bars: $50 \mu \mathrm{m}(\mathrm{A}), 10 \mu \mathrm{m}(\mathrm{B}, \mathrm{C}$, E), $65 \mu \mathrm{m}(\mathrm{D})$.

Fig. 5. Bayesian analysis of the small subunit rRNA gene sequences of representatives of the class Oligohymenophorea. Durchoniella sequences are in bold. Main haplotypes retrieved from Durchoniella species are represented by one sequence sharing $\geq 99 \%$ similarity with all other sequences. Each astome isolate was named with the initial of the city ( $R$ for Roscoff), the initial and the number of the site (SI for Souris Island), the worm number (ly), and the initial and the number of the Durchoniella species (Db: D. brasili, DI: D. legeriduboscqui and D: Durchoniella sp.). Maximum Likelihood bootstrap, posterior probability of Bayesian method, and Maximum Parsimony and Neighbour-Joining bootstrap values higher than $50 \%$ are shown at nodes on the phylogenetic tree. Black dots correspond to values of one (posterior probability) and 100\% (ML, MP, NJ). White dots correspond to values between $\geq 80 \%$. Outgroup sequences, not shown, were three ciliophoran sequences (Phyllopharyngea, AY378112; Colpodea, M97908; and Karyorelictea, GQ16715).

Fig. 6A-G. Epifluoresence (A-B) and transmission electron microscopy micrographs (C-G) of endocytoplasmic bacteria of Durchoniella species. Results of FISH with EUB338 general bacterial probe on $D$. brasili $(\mathbf{A})$ and $D$. legeriduboscqui $(\mathbf{B})$ showing bacteria most abundant in the ectoplasm of the host astomes. (C) Inset of an entire cell (scale bar $=5 \mu \mathrm{m}$ ) shows where the zoom was made. Note the numerous bacteria. (D) Single bacterium (scale bar $=200 \mathrm{~nm}$ ) with an enlarged view of the boxed region, CM: inner cytoplasmic membrane, CW: outer envelope (black arrows), and translucent halo membrane (white and black arrow). (E) Detail of coccoid bacteria. Note the electron-translucent halo around bacteria (arrowheads). (F) Rod- 
Sauvadet, et al.

shaped bacterium. (G) Possibly dividing cell of endocytoplasmic bacterium. Bars: 10

$\mu \mathrm{m}(\mathrm{A}), 20 \mu \mathrm{m}(\mathrm{B}), 500 \mathrm{~nm}(\mathrm{C}), 100 \mu \mathrm{m}(\mathrm{D}), 200 \mathrm{~nm}(\mathrm{E}, \mathrm{F}, \mathrm{G})$ 
Sauvadet, et al.
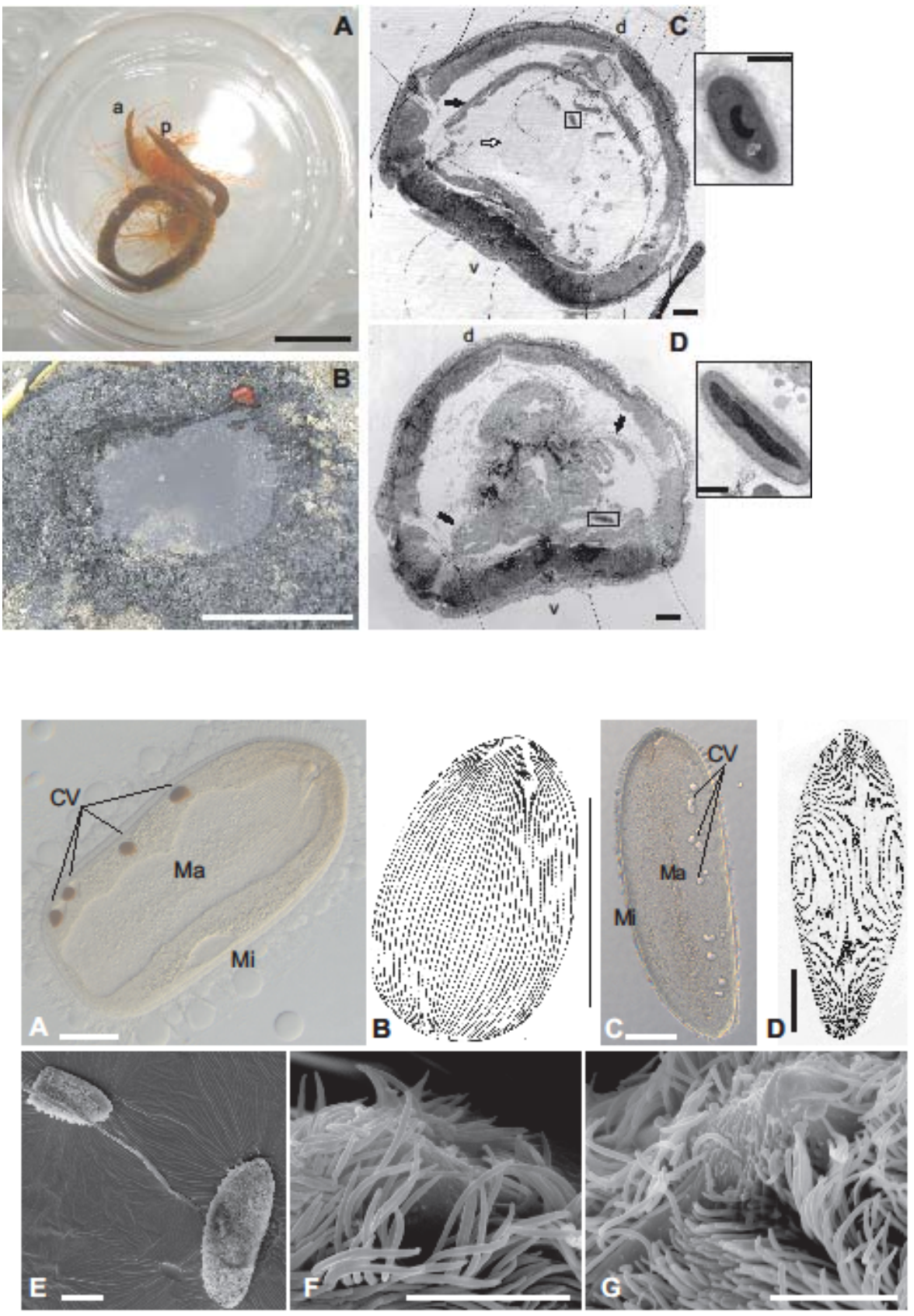
Sauvadet, et al.

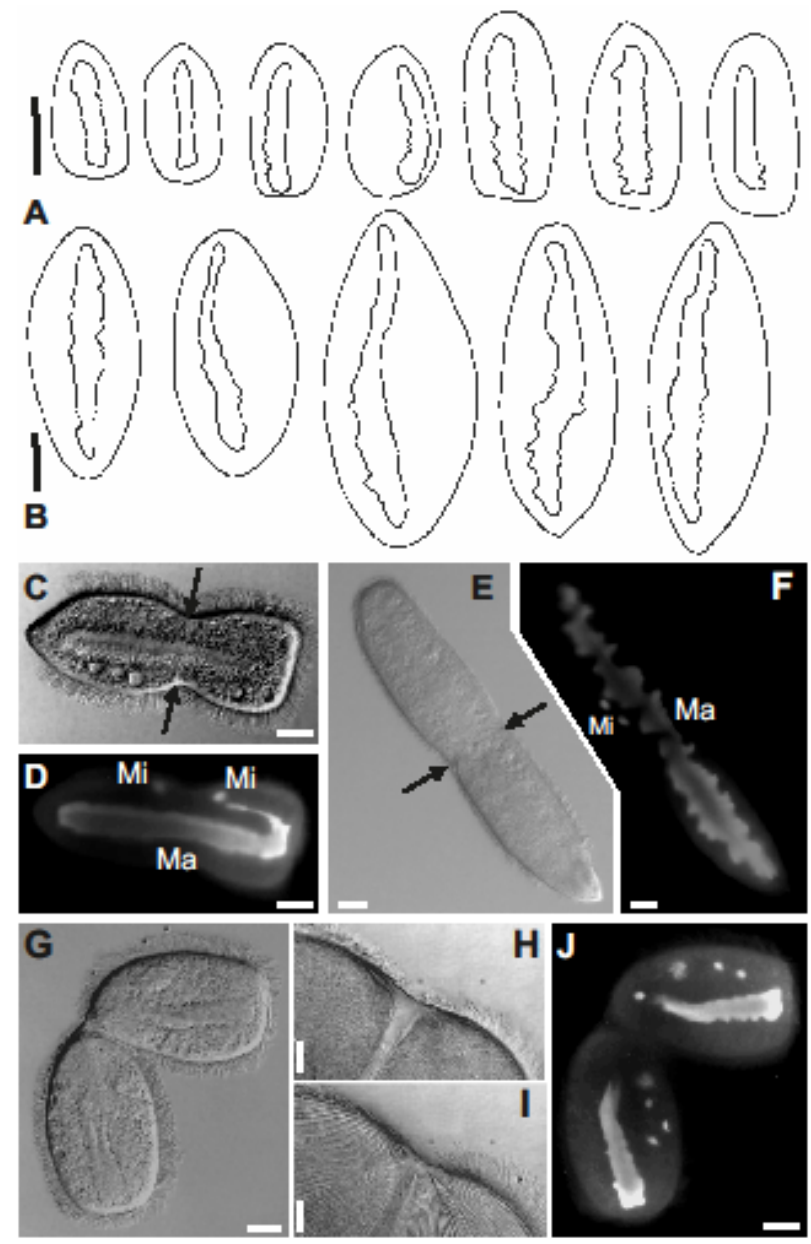


Sauvadet, et al.

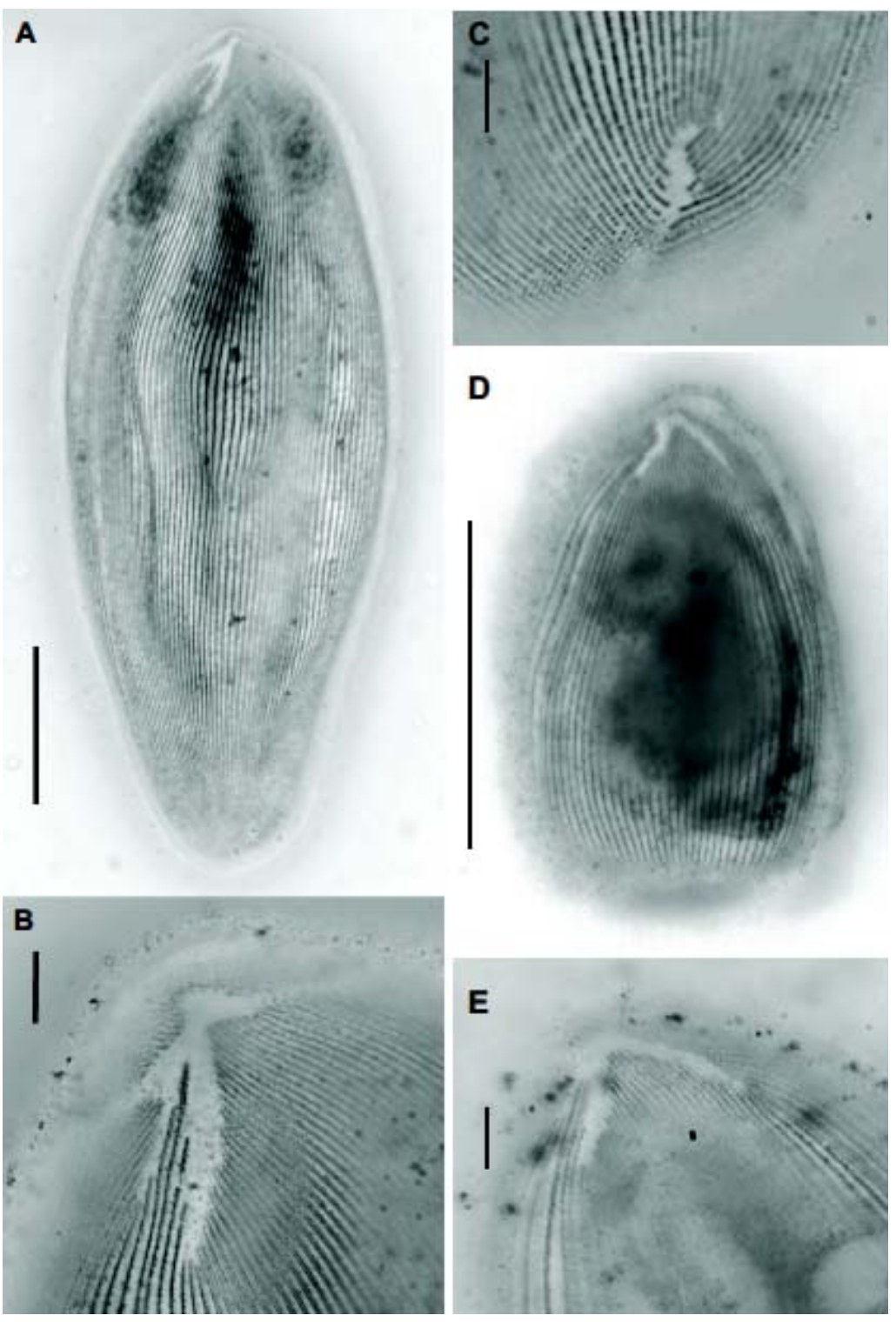


Sauvadet, et al.

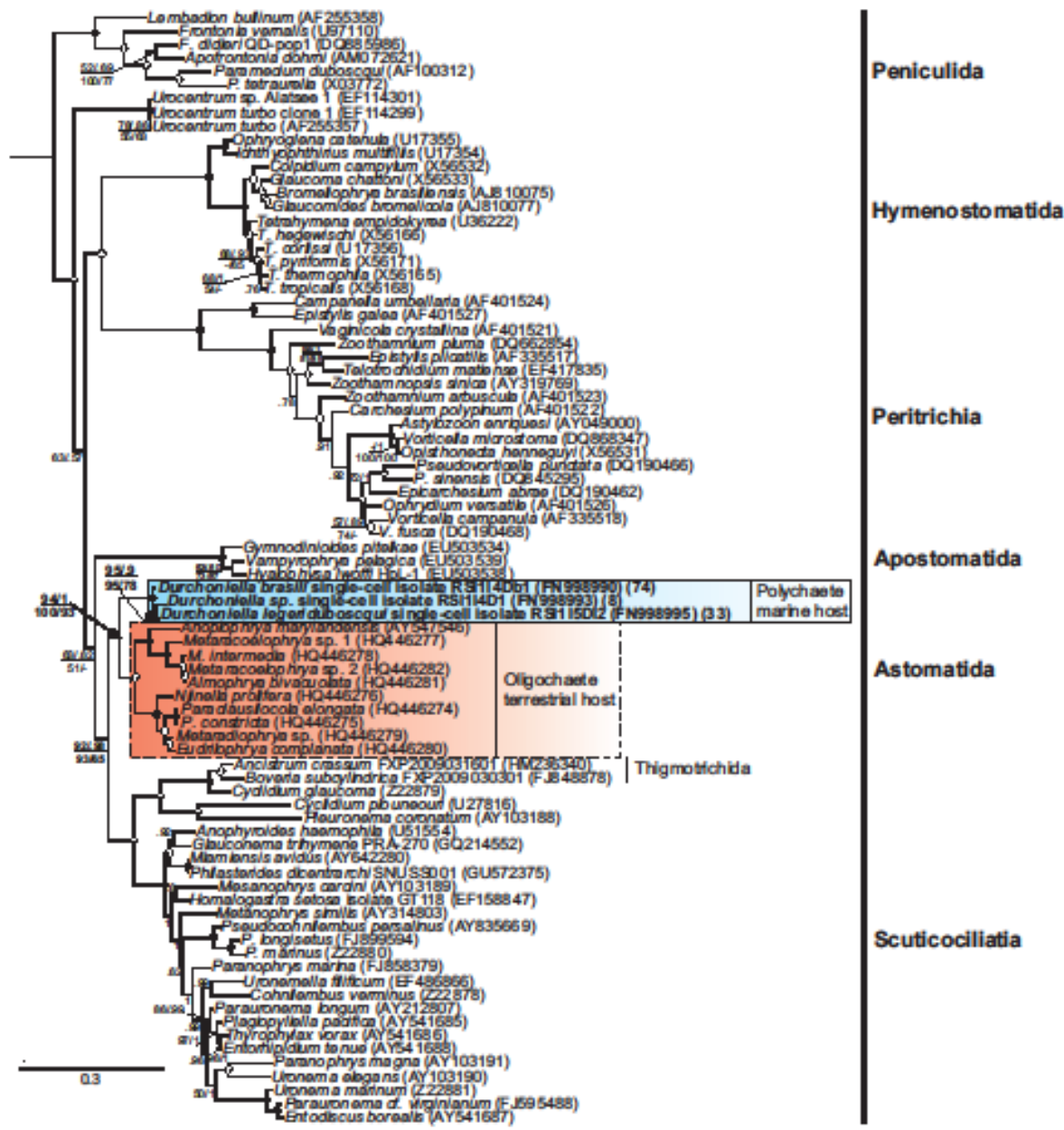


Sauvadet, et al.
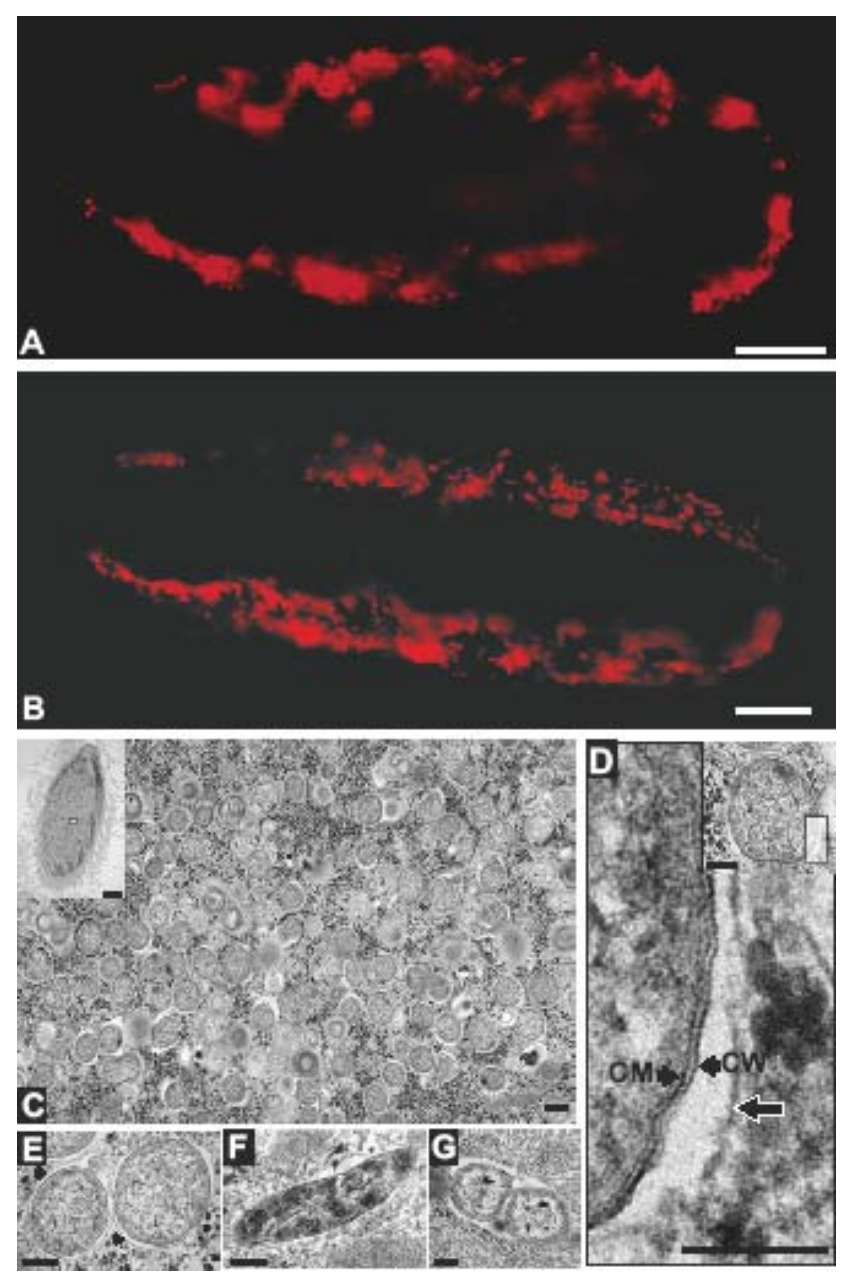
Table 1. Morphometric characterization of Durchoniella species from the intestine of the cirratulid polychaete Cirriformia tentaculata in the present study compared to those presented by Léger and Duboscq (1904) and de Puytorac (1954). Measurements of lengths and widths are given in micrometres with mean \pm standard deviation followed by range and sample size, where known.

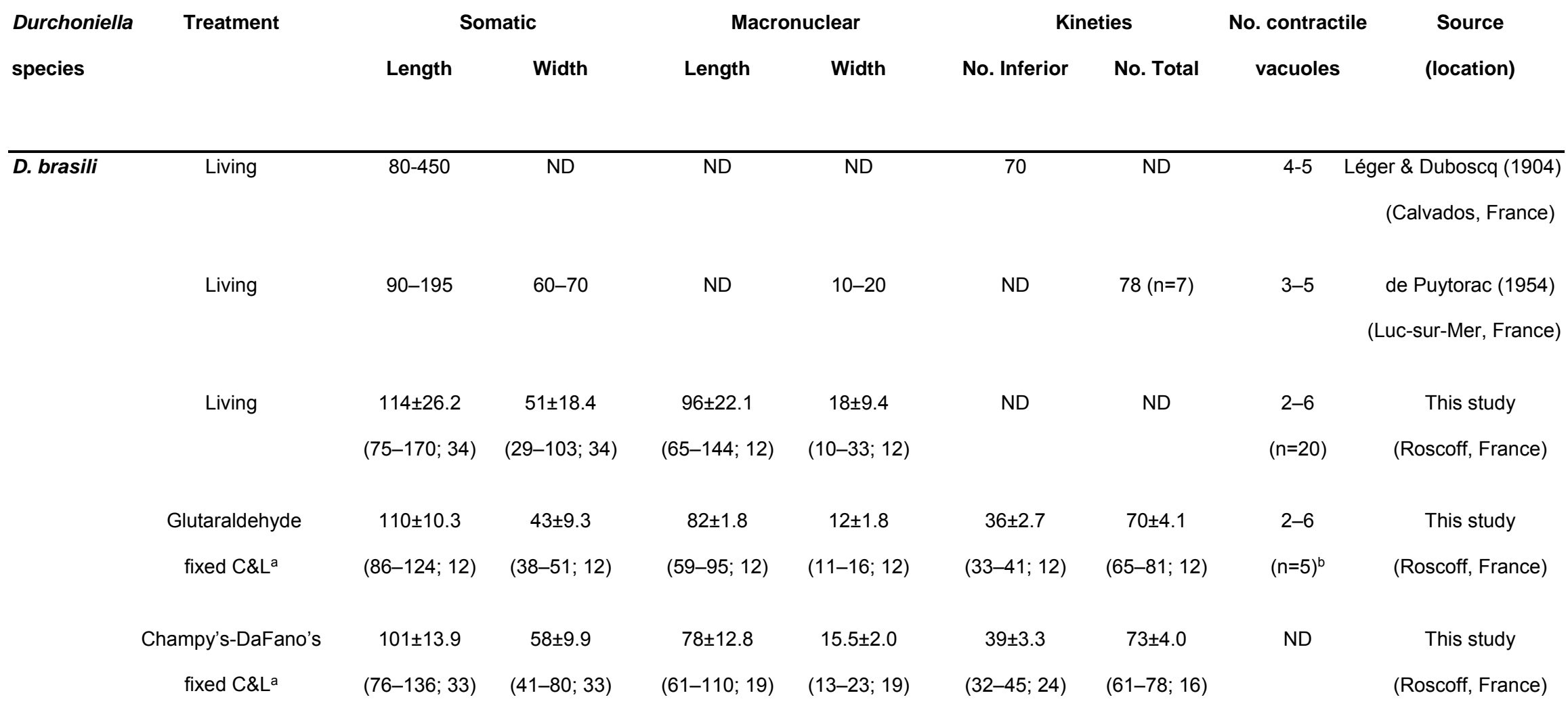


Sauvadet, et al.

\begin{tabular}{|c|c|c|c|c|c|c|c|c|c|}
\hline \multirow[t]{4}{*}{$\begin{array}{l}\text { D. legeri } \\
\text { duboscqui }\end{array}$} & Living & $180-350$ & 75-90 & ND & ND & ND & $138-140$ & $6-14$ & $\begin{array}{l}\text { de Puytorac (1954) } \\
\text { (Luc-sur-Mer, France) }\end{array}$ \\
\hline & Living & $\begin{array}{c}314 \pm 52.5 \\
(230-400 ; 21)\end{array}$ & $\begin{array}{c}119 \pm 36.4 \\
(68-183 ; 21)\end{array}$ & $\begin{array}{c}314 \pm 20.8 \\
(277-340 ; 6)\end{array}$ & $\begin{array}{c}75 \pm 19.8 \\
(49-97 ; 6)\end{array}$ & ND & ND & $\begin{array}{l}6-15 \\
(n=15)\end{array}$ & $\begin{array}{c}\text { This study } \\
\text { (Roscoff, France) }\end{array}$ \\
\hline & $\begin{array}{l}\text { Glutaraldehyde } \\
\text { fixed } C \& L^{a}\end{array}$ & $\begin{array}{c}256 \pm 53.2 \\
(182-369 ; 46)\end{array}$ & $\begin{array}{c}74 \pm 7.4 \\
(55-94 ; 46)\end{array}$ & $\begin{array}{c}228 \pm 52.5 \\
(154-338 ; 46)\end{array}$ & $\begin{array}{c}25 \pm 4.8 \\
(11-33 ; 46)\end{array}$ & $\begin{array}{c}53 \pm 2.5 \\
(48-61 ; 46)\end{array}$ & $\begin{array}{c}107 \pm 5.1 \\
(97-121 ; 46)\end{array}$ & $\begin{array}{c}8-13 \\
(n=16)^{b}\end{array}$ & $\begin{array}{l}\text { This study } \\
\left(\mathrm{Pl} / \mathrm{Po} / \mathrm{R}^{\mathrm{c}}\right)\end{array}$ \\
\hline & $\begin{array}{c}\text { Champy's-DaFano's } \\
\text { fixed C\&L }\end{array}$ & $\begin{array}{c}277 \pm 46.7 \\
(198-358 ; 31)\end{array}$ & $\begin{array}{c}111 \pm 19.9 \\
(72-171 ; 31)\end{array}$ & $\begin{array}{c}250 \pm 49.7 \\
(182-336 ; 16)\end{array}$ & $\begin{array}{c}29 \pm 6.3 \\
(17-44 ; 16)\end{array}$ & $\begin{array}{c}57 \pm 4.3 \\
(49-67 ; 29)\end{array}$ & $\begin{array}{c}115 \pm 8.5 \\
(103-128 ; 8)\end{array}$ & ND & $\begin{array}{c}\text { This study } \\
\text { (Roscoff, France) }\end{array}$ \\
\hline
\end{tabular}

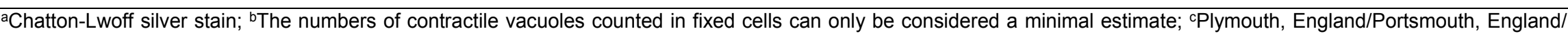
Roscoff, France. ND: Not Determined 
Table 1. Morphometric characterization of Durchoniella species from the intestine of the cirratulid polychaete Cirriformia tentaculata in the present study compared to those presented by Léger and Duboscq (1904) and de Puytorac (1954). Measurements of lengths and widths are given in micrometres with mean \pm standard deviation followed by range and sample size, where known.

\section{Somatic}

Macronuclear

Durchoniel

la species
Treatment

Length
Width

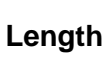

Length
Kineties

No.

Inferior
No.

contractil Source

Width

No. Tota

e

vacuoles

(location)

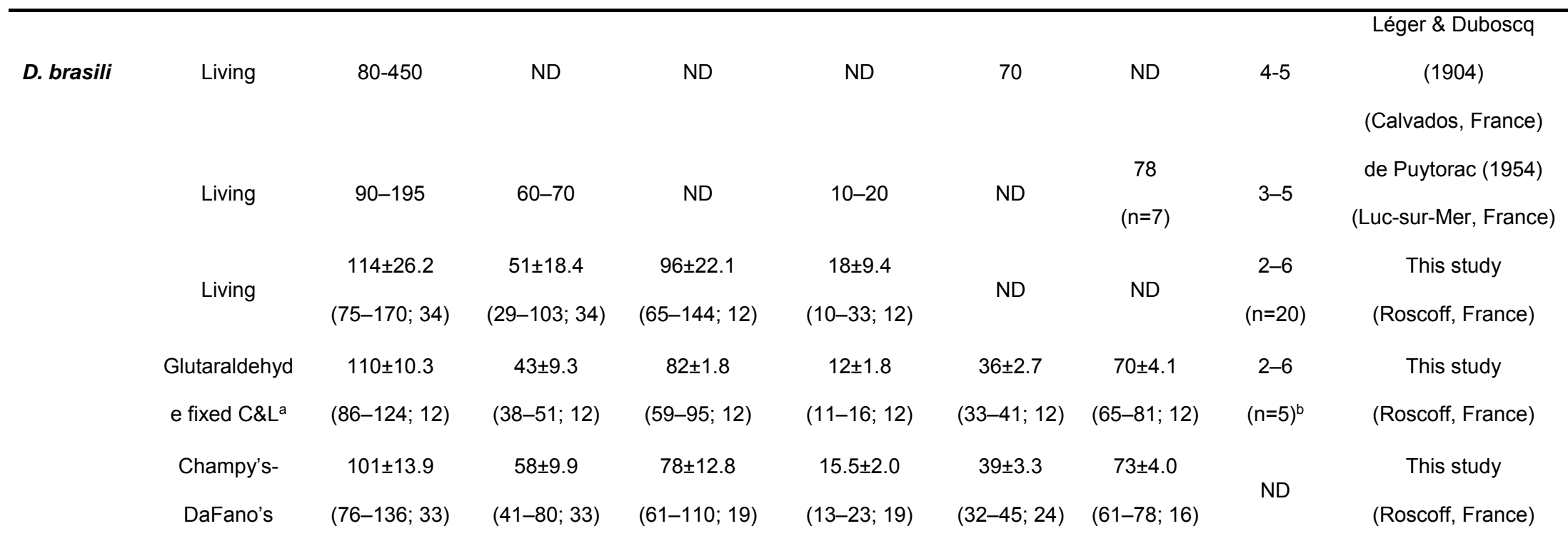


Sauvadet, et al

fixed C\&La

\begin{tabular}{|c|c|c|c|c|c|c|c|c|c|}
\hline $\begin{array}{l}\text { D. legeri } \\
\text { duboscqui }\end{array}$ & Living & $180-350$ & $75-90$ & ND & ND & ND & 138-140 & $6-14$ & $\begin{array}{l}\text { de Puytorac (1954) } \\
\text { (Luc-sur-Mer, France) }\end{array}$ \\
\hline & Living & $\begin{array}{c}314 \pm 52.5 \\
(230-400 ; 21)\end{array}$ & $\begin{array}{c}119 \pm 36.4 \\
(68-183 ; 21)\end{array}$ & $\begin{array}{c}314 \pm 20.8 \\
(277-340 ; 6)\end{array}$ & $\begin{array}{c}75 \pm 19.8 \\
(49-97 ; 6)\end{array}$ & ND & ND & $\begin{array}{l}6-15 \\
(n=15)\end{array}$ & $\begin{array}{l}\text { This study } \\
\text { (Roscoff, France) }\end{array}$ \\
\hline & $\begin{array}{l}\text { Glutaraldehyd } \\
\text { e fixed C\&L }{ }^{a}\end{array}$ & $\begin{array}{c}256 \pm 53.2 \\
(182-369 ; 46)\end{array}$ & $\begin{array}{c}74 \pm 7.4 \\
(55-94 ; 46)\end{array}$ & $\begin{array}{c}228 \pm 52.5 \\
(154-338 \\
46)\end{array}$ & $\begin{array}{c}25 \pm 4.8 \\
(11-33 ; 46)\end{array}$ & $\begin{array}{c}53 \pm 2.5 \\
(48-61 ; 46)\end{array}$ & $\begin{array}{c}107 \pm 5.1 \\
(97-121 \\
46)\end{array}$ & $\begin{array}{c}8-13 \\
(n=16)^{b}\end{array}$ & $\begin{array}{l}\text { This study } \\
\left(\mathrm{PI} / \mathrm{Po} / \mathrm{R}^{\mathrm{c}}\right)\end{array}$ \\
\hline & $\begin{array}{l}\text { Champy's- } \\
\text { DaFano's } \\
\text { fixed C\&La }\end{array}$ & $\begin{array}{c}277 \pm 46.7 \\
(198-358 ; 31)\end{array}$ & $\begin{array}{c}111 \pm 19.9 \\
(72-171 ; 31)\end{array}$ & $\begin{array}{c}250 \pm 49.7 \\
(182-336 \\
16)\end{array}$ & $\begin{array}{c}29 \pm 6.3 \\
(17-44 ; 16)\end{array}$ & $\begin{array}{c}57 \pm 4.3 \\
(49-67 ; 29)\end{array}$ & $\begin{array}{c}115 \pm 8.5 \\
(103-128 \\
8)\end{array}$ & ND & $\begin{array}{c}\text { This study } \\
\text { (Roscoff, France) }\end{array}$ \\
\hline
\end{tabular}

${ }^{\mathrm{a} C h a t t o n-L w o f f}$ silver stain; ${ }^{\mathrm{b}}$ The numbers of contractile vacuoles counted in fixed cells can only be considered a minimal estimate; ${ }^{\mathrm{c} P l y m o u t h,}$

England/Portsmouth, England/ Roscoff, France. ND: Not Determined 